\title{
Toward integrative cancer immunotherapy: targeting the tumor microenvironment
}

\author{
Leisha A Emens ${ }^{1,2,12^{*}}$, Samuel C Silverstein ${ }^{3,4}$, Samir Khleif ${ }^{5}$, Francesco M Marincola ${ }^{6,7}$ and Jérôme Galon ${ }^{8,9,10,11}$
}

\begin{abstract}
The development of cancer has historically been attributed to genomic alterations of normal host cells. Accordingly, the aim of most traditional cancer therapies has been to destroy the transformed cells themselves. There is now widespread appreciation that the progressive growth and metastatic spread of cancer cells requires the cooperation of normal host cells (endothelial cells, fibroblasts, other mesenchymal cells, and immune cells), both local to, and at sites distant from, the site at which malignant transformation occurs. It is the balance of these cellular interactions that both determines the natural history of the cancer, and influences its response to therapy. This active tumor-host dynamic has stimulated interest in the tumor microenvironment as a key target for both cancer diagnosis and therapy. Recent data has demonstrated both that the presence of $C D 8^{+} T$ cells within a tumor is associated with a good prognosis, and that the eradication of all malignantly transformed cells within a tumor requires that the intra-tumoral concentration of cytolytically active $\mathrm{CD} 8^{+}$effector $\mathrm{T}$ cells remain above a critical concentration until every tumor cell has been killed. These findings have stimulated two initiatives in the field of cancer immunotherapy that focus on the tumor microenvironment. The first is the development of the immune score as part of the routine diagnostic and prognostic evaluation of human cancers, and the second is the development of combinatorial immune-based therapies that reduce tumor-associated immune suppression to unleash pre-existing or therapeutically-induced tumor immunity. In support of these efforts, the Society for the Immunotherapy of Cancer (SITC) is sponsoring a workshop entitled "Focus on the Target: The Tumor Microenvironment" to be held October 24-25, 2012 in Bethesda, Maryland. This meeting should support development of the immune score, and result in a position paper highlighting opportunities for the development of integrative cancer immunotherapies that sculpt the tumor microenvironment to promote definitive tumor rejection.
\end{abstract}

\section{Introduction}

Historically, cancer therapies have largely focused on destroying the transformed cancer cell itself. Local therapies, including surgery and radiotherapy, aim to grossly neutralize malignancy, either by removing the tumor, or by destroying the replicative capacity of the cancer cells within it. Chemotherapy (and for some cancers endocrine therapy) classically exerts an anti-tumor effect by selectively disrupting an aspect of tumor cell biology that gives malignant cells a relative growth advantage compared to normal cells. More recently, innovative targeted therapies have been developed that selectively target and disrupt signaling pathways

\footnotetext{
* Correspondence: emensle@jhmi.edu

'Tumor Immunology and Breast Cancer Research Programs, Johns Hopkins University School of Medicine, Baltimore, MD 21231, USA Full list of author information is available at the end of the article
}

essential for tumor cell growth; examples include the HER-2-specific monoclonal antibody Trastuzumab for breast cancer, and the BRAF inhibitor vemurafenib for melanoma. Their use results in higher cure rates and less collateral damage to normal tissues than conventional chemotherapy or radiotherapy. Effectively sequencing these different treatment modalities and using combinations of drugs with complementary mechanisms of action and non-overlapping toxicities has reduced the mortality rates for many cancers [1].

There is now widespread appreciation that non-transformed host cells (endothelial cells, fibroblasts, other mesenchymal cells, and cells of the innate and adaptive immune systems) interact with malignant tumor cells to form a dynamic tumor microenvironment in which the non-transformed cells exert both positive and negative effects on the growth and spread of the cancer cells, and
C Biomed Central 
that these in turn affect the phenotype of the non-transformed host cells [2]. The balance of cellular and secretory-product interactions within this microenvironment determines whether the tumor mass regresses or grows, and whether the malignant cells remain in place, or metastasize to distant sites. In addition, these interactions can determine whether tumors respond well to radiation or systemic cancer therapy. These interactions likely also underlie the phenomenon of a mixed clinical response to therapy, where some metastases regress and others grow in response to the same treatment [3].

Over the last decade, the influence of host immune cells both within and surrounding tumors has emerged as a critical determinant of cancer biology, and a key factor in the success or failure of human cancer therapy [4]. Recognition of their impact has produced two major initiatives in the field of cancer immunotherapy: (1) the development of the "immune score" as a new and important component of the routine diagnostic and prognostic evaluation of human cancers [5], and (2) the development of combinatorial immune-based therapies that abrogate tumor-associated immune suppression in order to unleash the full tumoristatic and tumoricidal activity of pre-existing or therapeutically-induced immunity [6]. A deeper understanding of how cellular and molecular interactions within the tumor microenvironment sculpt the activities of innate and antigen-specific immune cells will lead to integrative cancer immunotherapies that selectively impinge on regulatory mechanisms within the tumor microenvironment to result in immune-based tumor rejection and clinical cure. To focus attention on these issues, the Society for the Immunotherapy of Cancer (SITC) is holding a workshop entitled "Focus on the Target: The Tumor Microenvironment" from October 24-25, 2012 in Bethesda, Maryland [7].

\section{The interplay of immunity and cancer growth and progression}

The Janus face of the immune system in cancer presents a complex challenge for tumor immunotherapy. Cells of the innate and acquired immune systems are involved in cellular transformation, in the establishment and growth of tumors, and in the metastasis of malignant tumor cells. Carcinogenesis results from the inflammation associated with a variety of chronic infections [8]. Cells of the immune system facilitate tumor progression and spread by selecting for tumor cells intrinsically capable of escaping immune recognition [4], by creating a tumor microenvironment that fosters disease progression [4], and by facilitating the local invasion and subsequent metastasis of tumor cells [9]. Conversely, cells of the innate and acquired immune systems can protect patients against both nascent and established cancers, either by destroying cancer cells directly, or by establishing and maintaining a state of tumor dormancy [4]. The influence of the immune system on the natural history of cancer is further highlighted by observations that the concentration of $\mathrm{CD}^{+} \mathrm{T}$ cells determines their killing efficiency in preclinical models [10], and that the quantity, quality, and location of tumor-infiltrating lymphocytes (TIL) are predictive of patient survival in cancer patients [11-14]. For example, in colon cancers, the density of $\mathrm{CD}^{+} \mathrm{T}$ cells within the tumor predicts patient survival [11-13]. Furthermore, for many cancers including colon cancer, the relative quantity and location of $\mathrm{CD}^{+}{ }^{+} \mathrm{T}$ cells and $\mathrm{CD} 4^{+} \mathrm{CD} 25^{+} \mathrm{FoxP}^{+}$regulatory $\mathrm{T}$ cells (Treg) are also key predictors of clinical outcome $[12,13]$. Genomic profiling of these "good prognosis," lymphocyte-infiltrated tumors typically reveals a striking signature of Th-1-type inflammation that includes markers of innate immune cell activation, chemokines that promote $\mathrm{T}$ cell trafficking into the tumor parenchyma, and expression of pro-inflammatory cytokines [13,15-19]. In parallel, a growing literature illustrates a role for the immune system in the clinical response to standard systemic cancer therapy. Individuals with breast cancer who carry a specific mutation of toll-like receptor 4 (TLR-4) have a higher risk of relapse after adjuvant anthracycline-based chemotherapy [20]. Patients with early breast cancers who are treated preoperatively with paclitaxel have new immune cell infiltrates within their tumors at the time of surgery [21]. Similarly, patients treated with Trastuzumab for breast cancer can develop tumor-specific $\mathrm{CD} 4^{+} \mathrm{T}$ lymphocytes within the peripheral blood [22], and within the breast tumor itself [23].

\section{The immune score}

An immune score that quantifies the intra-tumoral location and density of $\mathrm{CD}^{+} \mathrm{T}$ cells and memory CD45RO ${ }^{+} \mathrm{T}$ cells has been proposed as a useful approach both for predicting the impact of the tumor microenvironment on clinical outcome in colon cancer patients, and possibly for selecting therapy [13]. The clinical relevance of the immune score is that the intra-tumoral location and density of $\mathrm{CD}^{+} \mathrm{T}$ cells and memory $\mathrm{CD} 45 \mathrm{RO}^{+} \mathrm{T}$ cells are tightly correlated with disease-free and overall survival, and are, in fact, superior to the standard TNM staging system. Detailed analysis of colon cancer-associated lymphocytes reveals that a $\mathrm{T}$ helper type 1 profile is associated with a favorable prognosis, whereas a $\mathrm{T}$ helper type 17 profile is associated with a poor prognosis [24].

Other factors within the tumor microenvironment are also likely to influence the immune score, including other immune cells (intra-tumoral Treg, myeloid-derived suppressor cells, alternatively activated macrophages), 
stromal factors (fibroblasts, other mesenchymal cells, secretory products like tenascin [25]), and the integrity of the tumor cell genome. Of these factors, intratumoral Treg are one variable that has been associated with poor prognosis in many solid tumors (ovarian, breast, and pancreatic cancers), but paradoxically with favorable prognosis in colon cancer [26]. Whether cancer cell-specific genomic instability, associated with a more favorable prognosis in ovarian and colorectal cancers, is associated with or independent of the immune score remains to be determined [26,27]. Other elements of the tumor microenvironment also may shape the immune score [28]. For example, in lung cancer, low vascular endothelial growth factor-A (VEGF) and VEGF Receptor-2 expression in association with high concentrations of intra-tumoral $\mathrm{CD}^{+}$and $\mathrm{CD}^{+} \mathrm{T}$ cells is associated with a favorable prognosis [29].

Overall, the association of large numbers of tumorassociated $\mathrm{CD}^{+}, \mathrm{CD}_{4} \mathrm{RO}^{+}$, and granzyme $\mathrm{B}^{+} \mathrm{T}$ cells with improved clinical outcome suggests that these cells represent the cumulative interactions of diverse tumor and host-derived cells within the tumor microenvironment. A major initiative to measure and incorporate the numbers of relevant cytotoxic memory CD8 ${ }^{+} \mathrm{T}$ cells $\left(\mathrm{CD}^{+}, \mathrm{CD}^{+} 5 \mathrm{RO}^{+}\right.$, and granzyme $\mathrm{B}^{+} \mathrm{T}$ cells $)$ into standard clinical practice as a tumor immune score is underway [5]. A concept (based on the task force meeting "Immunoscoring as a New Possible Approach for the Classification of Cancer" convened in Naples, Italy February 13, 2012) will be presented at the SITC Workshop on the Tumor Microenvironment in October 2012. This will be followed by a "Workshop in Immune Scoring" in Naples, Italy in December 2012 that will recommend approaches to the harmonization of methods for immune scoring of tumors, and seek acceptance and implementation of immune scoring as a standard practice in the diagnosis and classification of cancers.

\section{Re-sculpting the tumor microenvironment to promote tumor rejection}

Given the influence of the tumor microenvironment on cancer biology and overall clinical outcomes, cancer therapies that target host elements involved in cancer development are an increasingly important component of the standard of care for many cancer types. Agents that modulate the tumor microenvironment in wide clinical use today include therapeutic monoclonal antibodies that promote antibody-dependent cellular cytotoxicity (Trastuzumab for breast and gastric cancers and Rituximab for hematologic malignancies), drugs that target tumor neovascularization (bevacizumab, sunitinib, and sorafenib for a variety of cancers), and those that modify the bone microenvironment (the bisphosphonate zolendronate and the RANKL inhibitor denosumab for malignant bone disease).

There is increasing evidence that Trastuzumab [22], Rituximab, and other therapeutic monoclonal antibodies stimulate clinically relevant adaptive immune responses, and that they do so in part by cross-priming immune cells within the locoregional tumor microenvironment $[30,31]$. Trastuzumab-like monoclonal antibodies can promote the evolution of a tumor-specific central memory $\mathrm{CD}^{+} \mathrm{T}$ cell response in preclinical models [32], Bevacizumab can alleviate the dendritic cell-based immune suppression caused by VEGF [33], and sunitinib can diminish the suppressive influence of intratumoral myeloid-derived suppressor cells and $\mathrm{T}$ regulatory cells in both preclinical models [34], and in patients with renal cell carcinoma [35]. Treating established tumors with a monoclonal antibody specific for the VEGF receptor 2 as a single agent can induce tumorspecific $\mathrm{T}$ cell immunity associated with tumor rejection and protection from a subsequent tumor challenge in an immune competent preclinical model [36]. The bonemodifying drug zolendronate can augment the activity of dendritic cells and NK cells, thereby promoting activation of $\gamma \delta$ and $\alpha \beta \mathrm{T}$ cells [37]. It may also modulate the tumoristatic and tumoricidal activity of tumor-associated macrophages [38].

Importantly, immune-modulating drugs that directly promote anti-tumor immune responses (the sipuleucel$\mathrm{T}$ vaccine for prostate cancer and the immune checkpoint inhibitor Ipilimumab for melanoma) have become part of the standard of care. Building on these leads, Ipilimumab and Bevacizumab have been combined with tumor vaccines to explore whether they enhance vaccine potency $[39,40]$. Trastuzumab has been combined with distinct cancer vaccines to capitalize on the direct antitumor activity of the antibody as well as its ability to modulate tumor immunity by various mechanisms $[41,42]$. Delineation of the accessory pathways that control $\mathrm{T}$ cell activation has led to the development of targeted checkpoint inhibitors that can further support immune priming and $\mathrm{T}$ cell activity within the tumor microenvironment. Novel drugs that specifically target immune regulatory pathways (including toll-like receptor modulators [43], antibodies specific for the PD-1 pathway [44], the OX-40 pathway [45], and the CD40 pathways [46]) are a growing focus of clinical development. The impact of epigenetic therapy on tumor immunity is also an emerging area of investigation [47].

\section{Conclusions}

The findings that the proper concentration of tumorantigen specific $\mathrm{CD} 8^{+} \mathrm{T}$ cells is required to control tumor growth and eradicate antigen-expressing tumor cells in preclinical models, and that the relative numbers 
and distribution of $\mathrm{CD}^{+} \mathrm{T}$ cells in human cancers is associated with disease-free and overall survival define a target goal and biomarker for clinically effective cancer immunotherapy. To meet that goal, successful immunebased therapies will likely ultimately integrate strategies that induce, recruit, and deliver tumor antigen-specific effector cells by adoptive cellular therapy or active vaccination with approaches that maximize their antitumor activity by mitigating active pathways of immune suppression within the tumor microenvironment in a scientifically rational manner. Progress in cancer immunotherapy will also require better characterization of the tumor-homing capacities, intratumoral concentration, lifespan, and functional activity of tumor antigenspecific effector $\mathrm{T}$ cells. The successful clinical development of such integrative cancer immunotherapies will require novel clinical trial designs that incorporate extensive blood, tissue, and imaging correlates in order to develop strategies that predict the likelihood of tumor response to immunotherapy, and evaluate immune and clinical responses in real time by imaging or tissue sampling. The overall goal of the 2012 SITC Workshop "Focus on the Target: The Tumor Microenvironment" is to focus on distinct aspects of the hosttumor interaction, and their implications for tumor immunotherapy. By systematically applying the best science to re-shape the host-tumor interaction, we will develop personalized, integrative cancer immunotherapies capable of inducing tumor rejection and effecting cure.

\section{Author details}

'Tumor Immunology and Breast Cancer Research Programs, Johns Hopkins University School of Medicine, Baltimore, MD 21231, USA. ${ }^{2}$ Department of Oncology, Johns Hopkins University School of Medicine, Baltimore, MD 21231, USA. ${ }^{3}$ Department of Physiology and Cellular Biophysics, Columbia University College of Physicians and Surgeons, New York, NY 10032, USA. ${ }^{4}$ Department of Medicine, Columbia University College of Physicians and Surgeons, New York, NY 10032, USA. ${ }^{5}$ Georgia Health Sciences University (GHSU) Cancer Center, Georgia, USA. Infectious Diseases and Immunogenetics Section (IDIS), National Institutes of Health, Bethesda, MD 20891, USA. 'Department of Transfusion Medicine, Clinical Center and trans$\mathrm{NIH}$ Center for Human Immunology (CHI), National Institutes of Health, Bethesda, MD 20891, USA. ${ }^{8}$ INSERM, UMRS872, Cordeliers Research Centre, Laboratory of Integrative Cancer Immunology, Paris F-75006, France.

${ }^{9}$ Assistance Publique-Hopitaux de Paris, AP-HP, Georges Pompidou European Hospital, Paris, France. ${ }^{10}$ Université Paris Descartes, Paris, France. ${ }^{11}$ Université Pierre et Marie Curie Paris 6, Paris, France. ${ }^{12}$ The Sidney Kimmel Comprehensive Cancer Center at Johns Hopkins, Johns Hopkins University, 1650 Orleans Street, Room 409, Bunting Blaustein Cancer Research Building, Baltimore, MD 21231-1000, USA.
}

Received: 19 March 2012 Accepted: 10 April 2012

Published: 10 April 2012

\section{References}

1. Siegel R, Naishadham D, Jemal A: Cancer statistics, 2012. CA Cancer J Clin 2012, 62:10-29.

2. Friedl $P$, Alexander $S$ : Cancer invasion and the microenvironment: plasticity and reciprocity. Cell 2012, 147:992-1009.
3. Carretero R, Wang E, Rodriguez Al, Reinboth J, Ascierto ML, Engle AM, Liu H, Camacho FM, Marincola FM, Garrido F, Cabrera T: Regression of melanoma metastases after immunotherapy is associated with activation of antigen presentation and interferon-mediated rejection genes. Int J Cancer 2011.

4. Schreiber RD, Old LJ, Smyth MJ: Cancer immunoediting: integrating immunity's roles in cancer suppression and promotion. Science 2011, 331:1565-1570.

5. Galon J, Pages F, Marincola FM, Thurin M, Trinchieri G, Fox BA, Gajewski TF, Ascierto PA: The immune score as a new possible approach for the classification of cancer. J Transl Med 2012, 10:1-4.

6. Topalian SL, Weiner GJ, Pardoll DM: Cancer immunotherapy comes of age. J Clin Oncol 2011, 29:4828-4836.

7. Galon J, Emens LA, Silverstein SC, Klief S, Marincola FM, organizers: Focus on the Target: The Tumor Microenvironment.[http://www.sitcancer.org/ meetings/am12/workshop12].

8. Kuraishy A, Karin M, Grivennikov SI: Tumor promotion via injury- and death-induced inflammation. Immunity 2011, 35:467-477.

9. Condeelis J, Pollard JW: Macrophages: obligate partners for tumor cell migration, invasion, and metastasis. Cell 2006, 124:263-266.

10. Budhu S, Loike JD, Pandolfi A, Han S, Catalano G, Constantinescu A, Clynes R, Silverstein SC: $\mathrm{CD}^{+} \mathrm{T}$ cell concentration determines their efficiency in killing cognate antigen-expressing syngeneic mammalian cells in vitro and in mouse tissues. J Exp Med 2010, 207:223-235.

11. Pages F, Berger A, Camus M, Sanchez-Cabo F, Costes A, Molidor R, Mlecknik B, Kirilovksy A, Nilsson M, Damotte D, et al: Effector memory T cells, early metastasis, and survival in colorectal cancer. N Engl J Med 2005, 353:2654-2666.

12. Galon J, Costes A, Sanchez-Cabo F, Kirilovsky A, Miecnik B, Lagorce-Pages C, Tosolini M, Camus M, Berger A, Wind P, et al: Type, density, and location of immune cells within human colorectal tumors predict clinical outcome. Science 2006, 313:1960-1964.

13. Mlecnik B, Tosolini M, Kirilovsky A, Berger A, Bindea G, Meatchi T, Bruneval P, Trajanoski Z, Fridman WH, Pages F, Galon J: Histopathologicbased prognostic factors of colorectal cancers are associated with the state of the local immune reaction. J Clin Oncol 2011, 29:610-618.

14. Ladoire S, Mignot G, Dabakuyo S, Arnould L, Apetoh L, Rebe C, Coudert B, Martin F, Bizollon MH, Vanoli A, et al: In situ immune response after neoadjuvant chemotherapy for breast cancer predicts survival. J Pathol 2011, 224:389-400

15. Shimizu K, Nakata M, Hirami Y, Yukawa T, Maeda A, Tanemoto K: Tumor infiltrating Fox $\mathrm{P3}^{+}$regulatory $\mathrm{T}$ cells are correlated with cyclooxygenase2 expression and are associated with recurrence in resected non-small cell lung cancer. J Thorac Oncol 2010, 5:585-590.

16. Ladoire S, Martin F, Ghiringhelli F: Prognostic role of FOXP3 ${ }^{+}$regulatory $\mathrm{T}$ cells infiltrating human carcinomas: the paradox of colorectal cancer. Cancer Immunol Immunother 2011, 60:909-918.

17. Gajewski TJ, Louahed J, Brichard VG: Gene signature in melanoma associated with clinical activity: a potential clue to unlock cancer immunotherapy. Cancer J 2010, 16:399-403.

18. Wang E, Miller LD, Ohnmacht GA, Mocellin S, Perez-Diaz A, Petersen D, Zhao Y, Simon R, Powell Jl, Asaki E, et al: Prospective molecular profiling of melanoma metastases suggests classifiers of immune responsiveness. Cancer Res 2001, 62:3581-3586.

19. Ascierto ML, De Giorgi V, Liu Q, Bedognetti D, Spivey TL, Murtas D, Uccellini L, Ayotte BD, Stroncek DF, Chouchane L, Manjili MH, Wang E, Marincola FM: An immunologic portrait of cancer. J Transl Med 2011, 9:146.

20. Apetoh L, Ghiringhelli jF, Tesniere A, Obeid M, Ortiz C, Criollo A, Mignot G, Maiuri MC, Ullrich E, Sauinier $P$, et al: Toll-like receptor 4-dependent contribution of the immune system to anticancer chemotherapy and radiotherapy. Nature Med 2007, 13:1050-1059.

21. Demaria S, Volm MD, Shapiro RL, Yee HT, Oratz R, Formenti SC, Mugia F, Symmans WF: Development of tumor-infiltrating lymphocytes in breast cancer after neoadjuvant paclitaxel chemotherapy. Clin Cancer Res 2001, 7:3025-3030

22. Taylor C, Hershman D, Shah N, Suciu-Foca N, Petrylak DP, Taub R, Vahdat L, Cheng B, Pegram M, Knutson KL, Clynes R: Augmented HER-2-specific immunity during treatment with trastuzumab and chemotherapy. Clin Cancer Res 2007, 13:5133-5143. 
23. Ladoire S, Arnould L, Mignot G, Apetoh L, Rebe C, Martin F, Fumoleau P Coudert B, Ghiringhelli F: T-bet expression in intratumoral lymphoid structures after neoadjuvant trastuzumab plus docetaxel for HER-2overexpressing breast carcinoma predicts survival. Br J Cancer 2011, 105:366-371.

24. Tosolini M, Kirilovsky A, Mlecnik B, Fredriksen T, Mauger S, Bindea G, Berger A, Bruneval P, Fridman WH, Pages F, Galon J: Clinical impact of different classes of infiltrating T cytotoxic and helper cells (Th1, Th2, Treg, Th17) in patients with colorectal cancer. Cancer Res 2011, 71:1263-1271.

25. Loike JD, Cao L, Budhu S, Hoffman S, Silverstein SC: Blockade of $a_{5} \beta_{1}$ integrins reverses the inhibitory effect of tenascin on chemotaxis of human monocytes and polymorphonuclear leukocytes through threedimensional gels of extracellular matrix proteins. J Immunol 2001 166:7534-7542.

26. Broussard EK, Disis ML: TNM staging in colorectal cancer: $\mathrm{T}$ is for $\mathrm{T}$ cell and $\mathrm{M}$ is for memory. J Clin Oncol 2011, 29:601-603.

27. McAlpine JN, Porter $H$, Kobel M, Nelson BH, Prentice LM, Kalloger SE, Senz J, Milne K, Ding J, Shah S, Huntsman DG, Gilks CB: BRCA1 and BRCA2 mutations correlate with TP53 abnormalities and presence of immune cell infiltrates in ovarian high-grade serous carcinoma. Modern Pathol, 20.

28. Gorgun G, Anderson KC: Intrinsic modulation of lymphocyte function by stromal cell network: advance in therapeutic targeting of cancer. Immunother 2011, 3:1253-1264.

29. Donnem T, Al-Shibli K, Andersen S, Al-Saad S, Busund KT, Bremnes RM: Combination of low vascular endothelial growth factor A (VEGF-A/VEGF receptor 2 expression and high lymphocyte infiltration is a strong and independent favorable prognostic factor in patients with nonsmall cell lung cancer. Cancer 2010, 116:4318-4325.

30. Ferris RL, Jaffee EM, Ferrone S: Tumor-antigen-targeted, monoclonal antibody-based immunotherapy: clinical response, cellular immunity, and immunoescape. J Clin Oncol 2010, 28:4390-4399.

31. Emens LA: Driving effective tumor immunity with combinatorial immunotherapy. In American Society of Clinical Oncology 2010 Educational Book. Edited by: Govindan R. Alexandria, VA: American Society of Clinical Oncology; 2010:460-465.

32. Kim PS, Armstrong TD, Song $H$, Wolpoe ME, Weiss $V$, Manning EA Huang LQ, Murata S, Sgouros G, Emens LA, Reilly RT, Jaffee EM: Antibody association with HER-2/neu-targeted vaccine enhances $\mathrm{CD} 8^{+} \mathrm{T}$ cell responses in mice through Fc-mediated activation of DCs. J Clin Invest 2008, 188:1700-1711.

33. Gabrilovich DI, Ishida T, Nadaf S, Ohm JE, Carbone DP: Antibodies to vascular endothelial growth factor enhance the efficacy of cancer immunotherapy by improving endogenous dendritic cell function. Clin Cancer Res 1999, 5:2963-2970.

34. Ozao-Choy J, Ma G, Kao J, Wang GX, Meseck M, Sung M, Schwartz M, Divino CM, Pan PY, Chen SH: The novel role of tyrosine kinase inhibitor in the reversal of immune suppression and modulation of tumor microenvironment for immune-based cancer therapies. Cancer Res 2009, 69:2514-2522.

35. Ko JS, Zea AH, Rini BH, Ireland JL, Elson P, Cohen P, Golshayan A, Rayman PA, Wood L, Garcia J, Dreicer R, Bukowski R, Finke JH: Sunitinib mediates reversal of myeloid-derived suppressor cell accumulation in renal cell carcinoma patients. Clin Cancer Res 2009, 15:2148-2157.

36. Manning EA, Ullman JG, Leatherman JM, Asquith JM, Hansen TR, Armstrong TD, Hicklin DJ, Jaffee EM, Emens LA: A vascular endothelial growth factor receptor-2 inhibitor enhances antitumor immunity through an immune-based mechanism. Clin Cancer Res 2007, 13:3951-3959.

37. Castella B, Riganti C, Fiore F, Pantaleoni F, Canepari ME, Peola S, Foglietta M, Palumbo A, Bosia A, Coscia M, Boccadoro M, Massaia M: Immune modulation by zolendronic acid in human myeloma: an advantageous cross-talk between Vy9V $\delta 2 \mathrm{~T}$ cells, a $\mathrm{CD}^{+} \mathrm{T}$ cells, regulatory T cells, and dendritic cells. J Immunol 2011, 187:1578-1590.

38. Rogers $T L$, Holen I: Tumour macrophages as potential targets of bisphosphonates. J Trans/ Med 2011, 9:177-180.

39. Hodi FS, O'Day SJ, McDermott DF, Weber RW, Sosman JA, Haanen JB, Gonzalez R, Robert C, Schadendorf D, Hassel JC, et al: Improved survival with ipilimumab in patients with metastatic melanoma. N Engl J Med 2010, 363:711-723
40. Rini Bl, Weinberg V, Fong L, Conry S, Hershberg RM, Small EJ: Combination immunotherapy with prostatic acid phosphatase pulsed antigenpresenting cells (Provenge) plus bevacizumab in patients with serologic progression of prostate cancer after definitive local therapy. Cancer 2006, 107:67-74

41. Disis ML, Wallace DR, Gooley TA, Dang Y, Slota M, Lu H, Coveler AL, Childs JS, Higgins DM, Flntak PA, dela Rosa C, Tietje K, Link J, Waisman J, Salazar LG: Concurrent trastuzumab and HER-2/neu-specific vaccination in patients with metastatic breast cancer. J Clin Oncol 2009, 27:4685-4692.

42. Emens LA, Gupta R, Petrik S, Laiko M, Levi J, Leatherman JM, Asquith JM, Daphtary MM, Garrett-Mayer E, Kobrin B, et al: A feasibility study of combination therapy with trastuzumab (T), cyclophosphamide (CY), and an allogeneic GM-CSF-secreting breast tumor vaccine for the treatment of HER-2+ breast cancer [abstract]. J Clin Oncol 2011, 29:s2535.

43. Liau LM, Prins RM, Kiertscher SM, Odesa SK, Kremen TJ, Giovannone AJ, Lin JW, Chute DJ, Mischel PS, Cloughesy TF, Roth MD: Dendritic cell vaccination in glioblastoma patients induces systemic and intracranial $T$ cell responses modulated by the local central nervous system tumor microenvironment. Clin Cancer Res 2005, 11:5515-5525.

44. Brahmer JR, Drake CG, Wollner I, Powderly JD, Picus J, Sharfman WH, Stankevich E, Pons A, Salay TM, McMiller TL, et al: Phase I study of single agent anti-programmed death-1 (MDX-1106) in refractory solid tumors: safety, clinical activity, pharmacodynamics, and immunologic correlates. J Clin Oncol 2010, 28:3167-3175.

45. Jensen SM, Maston LD, Gough MJ, Ruby CE, Redmond WL, Crittenden M, Li Y, Puri S, Poehlein CH, Morris N, et al: Signaling through OX40 enhances tumor immunity. Semin Oncol 2010, 37:524-532.

46. Beatty GL, Chiorean EG, Fishman MP, Saboury B, Teifelbaum UR, Sun W, Huhn RD, Song W, Li D, Sharp LL, et al: CD40 agonists alter tumor stroma and show efficacy against pancreatic carcinoma in mice and humans. Science 2011, 331:1612-1616.

47. Dubovsky JA, Villagra A, Powers JJ, Wang HW, Pinilla-lbarz J, Sotomayor EM: Circumventing immune tolerance through epigenetic modification. Curr Pharm Des 2010, 16:268-276.

doi:10.1186/1479-5876-10-70

Cite this article as: Emens et al:: Toward integrative cancer

immunotherapy: targeting the tumor microenvironment. Journal of Translational Medicine 2012 10:70.

\section{Submit your next manuscript to BioMed Central and take full advantage of:}

- Convenient online submission

- Thorough peer review

- No space constraints or color figure charges

- Immediate publication on acceptance

- Inclusion in PubMed, CAS, Scopus and Google Scholar

- Research which is freely available for redistribution

Submit your manuscript at www.biomedcentral.com/submit
C Biomed Central 